\title{
KARAKTERISTIK DAN PENGARUH FAKTOR LINGKUNGAN TERHADAP PRODUKSI IKAN BANDENG (Chanos chanos) DI TAMBAK TANAH SULFAT MASAM KABUPATEN KONAWE SELATAN PROVINSI SULAWESI TENGGARA
}

\author{
Akhmad Mustafa dan Erna Ratnawati \\ Balai Penelitian dan Pengembangan Budidaya Air Payau \\ Jl. Makmur Dg Sitakka No. 129, Maros 90512, Sulawesi Selatan \\ E-mail:akhmadmustafa@yahoo.com
}

(Naskah diterima: 19 April 2013; Disetujui publikasi: 19 Juli 2013)

\begin{abstract}
ABSTRAK
Faktor lingkungan berupa kualitas tanah dan air tambak adalah faktor yang sangat menentukan produktivitas tambak termasuk produksi ikan bandeng. Namun demikian, belum ada informasi mengenai karakteristik dan pengaruh faktor lingkungan terhadap produktivitas tambak untuk ikan bandeng di klaster Tinanggea. Oleh karena itu, dilakukan penelitian yang bertujuan untuk mengetahui karakteristik dan pengaruh langsung atau tidak langsung kualitas tanah dan air terhadap produksi tambak tanah sulfat masam di klaster Tinanggea. Penelitian dilaksanakan di klaster Tinanggea yaitu Kecamatan Tinanggea, Palangga Selatan, Lainea, dan Laeya. Kualitas tanah ditetapkan sebagai peubah bebas dan eksogen; kualitas air sebagai peubah perantara, tergantung dan endogen; serta produksi ikan bandeng sebagai peubah tergantung dan endogen. Karakteristik lingkungan diketahui melalui aplikasi statistik deskriptif, sedangkan pengaruh faktor lingkungan diketahui melalui aplikasi analisis jalur. Hasil penelitian menunjukkan bahwa tanah tambak di klaster Tinanggea didominasi oleh tanah sulfat masam yang dicirikan dengan potensi kemasaman tinggi, kandungan unsur toksik tinggi, kandungan unsur hara makro rendah, dan tekstur tergolong kasar. Secara umum, kualitas air dapat mendukung budidaya ikan bandeng di tambak. Dari 20 peubah kualitas tanah yang dianalisis ternyata hanya dua peubah yang mempengaruhi produksi ikan bandeng yaitu: $\mathrm{pH}_{\mathrm{FOX}}$ tanah dan potensial redoks tanah, sedangkan dari 14 peubah kualitas air, ternyata hanya tiga peubah yang mempengaruhi produksi ikan bandeng di tambak tanah sulfat masam klaster Tinanggea yaitu: padatan tersuspensi total air, $\mathrm{pH}$ air, dan potensial redoks air. $\mathrm{pH}_{\mathrm{FOX}}$ tanah hanya berpengaruh nyata dengan pengaruh langsung sebesar 0,454 terhadap produksi, sedangkan potensial redoks tanah berpengaruh sangat nyata dengan pengaruh langsung sebesar -0,540 terhadap produksi. Padatan tersuspensi total air, $\mathrm{pH}$ air, dan potensial redoks air hanya berpengaruh nyata dengan pengaruh langsung masing-masing $-0,343 ; 0,532$; dan $-0,500$ terhadap produksi. Kedua peubah kualitas tanah yang berpengaruh terhadap produksi tersebut ternyata berpengaruh pula terhadap kualitas air tambak, tetapi hanya pada peubah $\mathrm{pH}$ air dan potensial redoks air.
\end{abstract}

KATA KUNCI: analisis jalur, lingkungan, tanah sulfat masam, tambak, Konawe Selatan

ABSTRACT: Characteristics and effects of environmental factors on milkfish (Chanos chanos) production in acid sulfate soil-affected brackishwater ponds in Tinanggea cluster, South Konawe Regency, Southeast Sulawesi Province. By: Akhmad Mustafa and Erna Ratnawati 
Environmental factors such as soil and water quality determine the production of milkfish (Chanos chanos). There has been no specific information on characteristics and effects of environmental factors on productivity of milkfish in Tinanggea cluster. Therefore, this research was carried out to determine characteristics as well as direct and indirect effects of soil and water quality on milkfish production which were reared in acid sulfate soil-affected brackishwater ponds in Tinanggea cluster. Research was conducted in brackishwater ponds located in Tinanggea cluster, including Tinanggea, South Palangga, Lainea and Laeya Subdistricts. Soil quality was defined as independent and exogenous variables. Water quality was defined as intermediate, dependent, and endogenous variables. Milkfish production was defined as dependent and endogenous variables. Environmental characteristics were analyzed using descriptive statistics, while effects of environmental factors on milkfish production were analyzed using path analysis. Results showed that brackishwater ponds in Tinanggea cluster were dominated by acid sulfate soil which is characterized by high potential acidity, high content of toxic element, low content of macro element and relatively coarse soil texture. In general, water quality is sufficient to support milkfish culture in brackishwater ponds. From twenty soil quality variables that were analyzed, only two variables ( $\mathrm{pH}_{\mathrm{FOX}}$ and redox potential) that have effect on milkfish production. From fourteen water quality variables that were analyzed, only three variables (total suspended solid, $\mathrm{pH}$ and redox potential) that have effect on milkfish production. $\mathrm{pH}_{\text {FOX }}$ of soil has significant effect with direct effect of 0.454 on milkfish production, while redox potential has hightly significant effect with direct effect of -0.540 on milkfish production. Total suspended solid, $\mathrm{pH}$ and redox potential of water have direct effect of $-0.343,0.532$, and -0.500 on milkfish production, respectively. $\mathrm{pH}_{\text {FOX }}$ and redox potential variables not only have effect on milkfish production, but also on water quality.

\section{KEYWORDS: path analysis, environment, acid sulfate soil, brackishwater pond, South Konawe}

\section{PENDAHULUAN}

Salah satu kabupaten di Sulawesi Tenggara yang telah ditetapkan sebagai pengembangan kawasan Minapolitan sesuai Keputusan Menteri Kelautan dan Perikanan Republik Indonesia Nomor KEP.32/MEN/2010 tentang Penetapan Kawasan Minapolitan adalah Kabupaten Konawe Selatan (Konsel). Telah ditetapkan pula bahwa komoditas andalan dalam Kawasan Minapolitan di daerah tersebut untuk budidaya tambak adalah udang dan ikan bandeng. Luas tambak di Kabupaten Konsel mencapai 4.825 ha dengan produksi 540 ton/tahun (Anonim, 2010) atau dengan produktivitas tambak $111,92 \mathrm{~kg} / \mathrm{ha} / \mathrm{tahun}$. Ikan bandeng (Chanos chanos) adalah komoditas yang umum dibudidayakan di tambak Kabupaten Konsel, baik secara monokultur maupun secara polikultur. Tambak di Kabupaten Konsel pada umumnya dibangun di lahan rawa di mana salah satu jenis tanahnya adalah tanah sulfat masam. Tanah sulfat masam adalah nama umum yang diberikan kepada tanah atau sedimen yang mengandung besi sulfida atau pirit (Dent, 1986; Sammut \& Lines-Kelly, 2000; Lin et al., 2004; Schaetzl \& Anderson, 2005).
Ketika tanah sulfat masam teroksidasi karena digali untuk dikonstruksi menjadi tambak maka terjadi penurunan $\mathrm{pH}$ lebih kecil dari 4,0. Akibat lebih lanjut, kelarutan unsurunsur toksik seperti Fe, Al dan Mn menjadi lebih tinggi yang dapat mematikan organisme yang dibudidayakan di tambak. Oleh karena itu, tambak tanah sulfat masam yang baru atau belum dikelola tanahnya secara tepat memiliki kandungan unsur-unsur toksik tinggi dan ketersediaan fosfat rendah. Dalam hal ini, kualitas tanah tambak tanah sulfat masam dapat mempengaruhi kualitas air tambak dan produksi organisme yang dibudidayakan. Telah dibuktikan pula bahwa kontak langsung udang windu (Penaeus monodon) dengan tanah dasar melalui aqueous phase merupakan salah satu penyebab rendahnya sintasan udang windu di tambak tanah sulfat masam (Mustafa, 2007). Boyd (1989) dan Sammut (1999) menyatakan bahwa tanah adalah faktor produksi utama dalam budidaya tambak, karena mempengaruhi kualitas air, proses biologis dan rekayasa tambak.

Secara umum, faktor lingkungan tambak (kualitas tanah dan air) adalah faktor penentu 
dominan dalam budidaya tambak sehingga dipertimbangkan sebagai kriteria dalam kesesuaian lahan untuk budidaya tambak (Muir \& Kapetsky, 1988; Boyd, 1995; Hardjowigeno et al., 1996; Treece, 2000; Salam et al., 2003; Karthik et al., 2005; Mustafa et al., 2007). Faktor lingkungan tambak adalah faktor penting yang mempengaruhi produksi di tambak, termasuk tambak tanah sulfat masam (Mustafa \& Ratnawati, 2005; Mustafa \& Sammut, 2007). Namun demikian, belum ada informasi rinci mengenai hubungan sebab akibat dari kualitas tanah dan atau kualitas air dalam mempengaruhi produksi tambak tanah sulfat masam. Oleh karena itu, dilakukan penelitian yang bertujuan untuk mengkarakteristik lingkungan tambak dan menganalisis hubungan kausal antarpeubah kualitas tanah dan kualitas air dan produksi tambak dengan tujuan untuk mengetahui pengaruh langsung atau tidak langsung kualitas tanah dan air terhadap produksi ikan bandeng di tambak tanah sulfat masam di Kabupaten Konsel.

\section{BAHAN DAN METODE}

\section{Waktu dan Lokasi Penelitian}

Penelitian berupa pengambilan contoh tanah dan air serta wawancara dengan responden dilaksanakan pada bulan Maret dan April 2012 di klaster Tinanggea yang meliputi: Kecamatan Tinanggea, Palangga Selatan, Laiya, dan Lainea, Kabupaten Konsel, Provinsi Sulawesi Tenggara. Analisis kualitas tanah dan air masing-masing dilaksanakan di Laboratorium Tanah dan Laboratorium Air, Balai Penelitian dan Pengembangan Budidaya Air Payau, Maros Provinsi Sulawesi Selatan.

\section{Pengumpulan Data}

Metode yang diterapkan dalam penelitian adalah metode survai. Data yang dikumpulkan meliputi kualitas tanah dan kualitas air serta produksi tambak. Pengukuran dan pengambilan contoh tanah dilakukan pada kedalaman 0-0,25 $\mathrm{m}$. Kualitas tanah yang diukur secara in situ adalah $\mathrm{pH}_{\mathrm{F}}(\mathrm{pH}$ tanah yang diukur langsung di lapangan) dengan $\mathrm{pH}$-meter (Ahern et al., 2004), $\mathrm{pH}_{\mathrm{FOX}}$ ( $\mathrm{pH}$ tanah yang diukur di lapangan setelah dioksidasi dengan hidrogen peroksida 30\%) dengan pH-meter (Ahern et al., 2004) dan potensial redoks diukur dengan redox-meter. Untuk analisis peubah kualitas tanah lainnya, maka contoh tanah yang ada dalam kantong plastik dimasukkan dalam cool box yang berisi es sesuai petunjuk Ahern et al. (2004). Karena seluruh contoh tanah adalah tanah sulfat masam, maka contoh tanah diovenkan pada suhu $80^{\circ} \mathrm{C}-85^{\circ} \mathrm{C}$ selama 48 jam (Ahern et al., 2004). Setelah kering, contoh tanah dihaluskan dengan cara ditumbuk pada lumpang porselin dan diayak dengan ayakan ukuran lubang 2,0 dan 0,5 mm. Kualitas tanah yang dianalisis di laboratorium meliputi $\mathrm{pH}_{\mathrm{KCl}}(\mathrm{pH}$ dari ekstrak KCl) (McElnea \& Ahern, 2004a), $\mathrm{pH}_{\text {ox }}$ (McElnea \& Ahern, 2004b), $S_{p}$ (sulfur peroksida) (Melville, 1993; McElnea \& Ahern, 2004c), $\mathrm{S}_{\mathrm{KCl}}$ (sulfur yang diekstrak dengan $\mathrm{KCl}$ ) (Melville, 1993; McElnea \& Ahern, 2004d), $\mathrm{S}_{\mathrm{POS}}\left(\mathrm{S}_{\mathrm{P}}-\mathrm{S}_{\mathrm{KC}}\right)$ (Ahern \& McElnea, 2004), TPA (Titratable Peroxide Acidity) (McElnea \& Ahern, 2004b), TAA (Titratable Actual Acidity) (McElnea \& Ahern, 2004a), TSA (Titratable Sulfidic Acidity) (TPATAA) (McElnea \& Ahern, 2004b), pirit (Ahern et al., 1998a, 1998b), karbon organik dengan metode Walkley dan Black (Eviati \& Sulaeman, 2009), N-total dengan metode Kjedhal (Eviati \& Sulaeman, 2009), $\mathrm{PO}_{4}$ dengan metode Bray 1 (Eviati \& Sulaeman, 2009), Fe dengan spektrofotometer (Menon, 1973), Al dengan spektrofotometer (Menon, 1973) dan tekstur dengan metode hidrometer (Agus et al., 2006).

Pengukuran dan pengambilan contoh air di tambak mengikuti titik pengambilan contoh tanah. Peubah kualitas air yang diukur langsung di lapangan adalah suhu, salinitas, oksigen terlarut, dan $\mathrm{pH}$ dengan menggunakan Hydrolab $^{\circledR}$ Minisonde. Contoh air untuk analisis di laboratorium diambil dengan menggunakan Kmerer Water Sampler dan dipreservasi mengikuti petunjuk APHA (2005). Peubah kualitas air yang dianalisis di laboratorium meliputi: $\mathrm{NH}_{3}$ (metode fenat), $\mathrm{NO}_{3}$ (metode reduksi kadmium), $\mathrm{NO}_{2}$ (metode kolorimetri), $\mathrm{PO}_{4}$ (metode asam askorbat), Fe (metode penantrolin), $\mathrm{SO}_{4}$ (metode turbidimetri), $\mathrm{SiO}_{2}$ (metode molibdo silikat), bahan organik total (metode basa), dan padatan tersuspensi total (metode gravimetri) mengikuti petunjuk Menon (1973), Parsons et al. (1989), APHA (2005) serta Sutrisyani \& Rohani (2009).

Data produksi tambak diperoleh melalui wawancara dengan mengajukan kuesioner secara terstruktur terhadap responden. Produksi tambak yang dicatat adalah produksi tiga tahun terakhir atau enam siklus terakhir yang selanjutnya dirata-ratakan. Responden terpilih adalah pengelola dari tambak yang diukur dan diambil contoh tanah dan contoh airnya. 


\section{Analisis Data}

Statistik deskriptif berupa nilai minimum, maksimum, rata-rata, dan standar deviasi digunakan untuk analisis data setiap karakteristik lingkungan (peubah kualitas tanah dan air) serta produksi tambak. Uji Reliabilitas dan Uji Validitas dilakukan terhadap data yang diperoleh dari kuesioner yaitu produksi ikan bandeng di tambak. Dalam analisis jalur diterapkan model mediasi di mana peubah kualitas air (sebagai peubah perantara, peubah tergantung dan peubah endogen) memodifikasi pengaruh peubah kualitas tanah (sebagai peubah bebas dan peubah eksogen) terhadap produksi tambak (sebagai peubah tergantung dan peubah endogen), model rekursif di mana semua anak panah menuju satu arah, dan model persamaan dua jalur di mana peubah kualitas tanah sebagai peubah bebas dan peubah kualitas air dan produksi tambak sebagai peubah tergantung.

Koefisien korelasi ditentukan untuk mendeteksi adanya gejala multikolinearitas yaitu gejala korelasi antarpeubah kualitas tanah maupun kualitas air tambak. Untuk menghitung persamaan regresinya digunakan metode langkah mundur (backward) (Draper \& Smith, 1981). Koefisien korelasi kembali digunakan untuk mengetahui korelasi antarpeubah eksogen terpilih dan antarpeubah perantara terpilih dan gabungan peubah eksogen dan perantara. Uji R² (koefisien determinasi yang disesuaikan) digunakan untuk mengetahui besarnya peubah eksogen menjelaskan peubah perantara serta gabungan peubah eksogen dan perantara menjelaskan peubah tergantung. Uji F digunakan untuk menguji adanya hubungan linier antarpeubah eksogen maupun antara peubah eksogen dan perantara. Uji t digunakan untuk mengetahui besarnya pengaruh peubah eksogen terhadap peubah perantara secara sendiri-sendiri atau parsial serta besarnya pengaruh peubah eksogen dan perantara terhadap peubah tergantung secara parsial pula. Taraf signifikansi ditetapkan sebesar 0,10. Analisis jalur ini menggunakan bantuan program IBM (International Business Machines) SPSS (Statistical Product and Service Solution) Statistics 20.

Besarnya pengaruh peubah lain di luar model ditentukan dengan menghitung koefisien analisis jalur yang menunjukkan error dengan menggunakan persamaan (Widarjono, 2010; Suliyanto, 2011):

$$
P e=\sqrt{1-R^{2}}
$$

di mana:

$\mathrm{Pe}=$ Koefisien analisis jalur

$\mathrm{R}^{2}=$ Koefisien determinasi

Penentuan besarnya pengaruh, baik pengaruh langsung, pengaruh tidak langsung dan pengaruh total peubah eksogen terhadap peubah endogen dihitung berdasarkan petunjuk Rutherford \& Choe (1993), Everitt \& Dunn (2001), Supranto (2004), Amir (2006) dan Sarwono (2007). Diagram hasil analisis jalur dibuat dengan bantuan program AMOS (Analysis of Moment Structures) 16.0.

\section{HASIL DAN BAHASAN}

\section{Karakteristik Lingkungan dan Produksi Tambak}

Kabupaten Konsel Provinsi Sulawesi Tenggara memiliki 21 kecamatan di mana delapan di antaranya tergolong kecamatan pesisir (Anonim, 2010). Dalam pengembangan Kawasan Minapolitan di Kabupaten Konawe Selatan, di antara delapan kecamatan pesisir telah ditetapkan empat kecamatan yaitu: Tinanggea, Palangga Selatan, Laeya, dan Lainea yang kemudian dikenal dengan klaster Tinanggea sebagai salah satu klaster dalam pengembangan perikanan budidaya termasuk budidaya tambak seperti tertuang dalam Peraturan Bupati Konsel Nomor: 16 Tahun 2010 tentang Penetapan Kawasan Strategis Cepat Tumbuh Kabupaten Konawe Selatan yang antara lain menetapkan Kawasan Strategis Cepat Tumbuh Minapolitan.

Seperti telah dijelaskan sebelumnya, bahwa jenis tanah yang dijumpai di kawasan pertambakan klaster Tinanggea didominasi oleh tanah sulfat masam, sehingga peubah kualitas tanah yang dianalisis adalah peubah kualitas tanah yang khas atau menjadi ciri spesifik untuk tanah sulfat masam (Tabel 1). Rata-rata potensial redoks (Eh) tanah tambak di klaster Tinanggea bernilai negatif yaitu $-177,5 \mathrm{mV}$ yang menunjukkan bahwa tanah dalam kondisi tereduksi. Hal ini sebagai akibat dari tambak yang seluruhnya berisi isi air karena digunakan untuk budidaya ikan bandeng, sehingga terbentuk kondisi reduksi pada tanah dasar tambak.

$\mathrm{pH}_{\mathrm{F}}$ adalah $\mathrm{pH}$ tanah yang diukur di lapangan dalam kondisi tanah jenuh dengan air, 
Tabel 1. Statistik deskriptif produksi, kualitas tanah dan kualitas air tambak di klaster Tinanggea Kabupaten Konawe Selatan Provinsi Sulawesi Tenggara $(n=24)$

Table 1. Descriptive statistics of production, soil quality and water quality of brackishwater ponds in Tinanggea cluster, South Konawe Regency Southeast Sulawesi Province $(n=24)$

\begin{tabular}{|c|c|c|c|c|}
\hline $\begin{array}{l}\text { Fakt or/Peubah } \\
\text { Factor/Variable }\end{array}$ & Minimum & $\begin{array}{l}\text { Maksimum } \\
\text { Maximum }\end{array}$ & $\begin{array}{l}\text { Rata-rata } \\
\text { Average }\end{array}$ & $\begin{array}{c}\text { St andar deviasi } \\
\text { Standard } \\
\text { deviation }\end{array}$ \\
\hline \multicolumn{5}{|l|}{ Kualitas tanah (Soil quality): } \\
\hline Potensial redoks (Redox potential) (mV) & -346 & 31 & -177.5 & 109.86 \\
\hline $\mathrm{pH}_{\mathrm{F}}$ & 5.78 & 7.07 & 6.7 & 0.306 \\
\hline $\mathrm{pH}_{\mathrm{FOx}}$ & 0.74 & 5.7 & 3.24 & 1.789 \\
\hline $\mathrm{pH}_{\mathrm{F}}-\mathrm{pH}_{\mathrm{FOX}}$ & 0.82 & 6.01 & 3.46 & 1.881 \\
\hline $\mathrm{pH}_{\mathrm{KCl}}$ & 3.82 & 7.67 & 6.05 & 1.096 \\
\hline $\mathrm{pH}_{\mathrm{Ox}}$ & 0.9 & 5.07 & 2.21 & 1.099 \\
\hline $\operatorname{TPA}\left(\mathrm{mol} \mathrm{H}^{+} /\right.$ton $) /\left(\right.$mole $\mathrm{H}^{+} /$ton $)$ & 17 & $2,000.00$ & 647.7 & 616.9 \\
\hline $\mathrm{TAA}\left(\mathrm{mol} \mathrm{H}^{+} /\right.$ton $) /\left(\right.$mole $\mathrm{H}^{+} /$ton $)$ & 0 & 20 & 2.7 & 5.12 \\
\hline $\mathrm{TSA}\left(\mathrm{mol} \mathrm{H}^{+} /\right.$ton $) /\left(\right.$mole $\mathrm{H}^{+} /$ton $)$ & 3 & $2,000.00$ & 645 & 617.34 \\
\hline $\mathrm{S}_{\mathrm{KCl}}(\%)$ & 0.15 & 2.58 & 0.83 & 0.72 \\
\hline$S_{p}(\%)$ & 0.28 & 4.13 & 1.61 & $1.25 . .2$ \\
\hline $\mathrm{S}_{\mathrm{POS}}(\%)$ & 0.02 & 3.78 & 0.78 & 1.471 \\
\hline Pirit (Pyrite) (\%) & 0.01 & 8.93 & 2.88 & 2.756 \\
\hline $\mathrm{Fe}(\mathrm{mg} / \mathrm{L})$ & 449 & $3,917.00$ & $2,374.41$ & $1,375.08$ \\
\hline $\mathrm{Al}(\mathrm{mg} / \mathrm{L})$ & 59 & 770 & 290.01 & 166.234 \\
\hline Bahan organik (Organic matter) (\%) & 2.77 & 19.34 & 9.06 & 4.764 \\
\hline N-total (Total-N) (\%) & 0.11 & 0.55 & 0.25 & 0.126 \\
\hline $\mathrm{PO}_{4}(\mathrm{mg} / \mathrm{L})$ & 13.37 & 129.22 & 53.78 & 24.482 \\
\hline Pasir (Sand) (\%) & 48 & 92 & 73.1 & 11.48 \\
\hline Liat (Clay) (\%) & 0 & 20 & 3.5 & 5.17 \\
\hline Debu (Silt) (\%) & 0 & 50 & 23.5 & 12.19 \\
\hline \multicolumn{5}{|l|}{ Kualitas air (Water quality): } \\
\hline Suhu (Temperature) $\left({ }^{\circ} \mathrm{C}\right)$ & 29.39 & 36.44 & 32.95 & 1.837 \\
\hline Salinitas (Salinity) (ppt) & 2.63 & 31.04 & 13.42 & 6.345 \\
\hline $\mathrm{pH}$ & 6.29 & 8.68 & 7.31 & 0.564 \\
\hline Oksigen terlarut (Dissolved oxygen) (mg/L) & 5.85 & 9.42 & 6.84 & 0.677 \\
\hline Potensial redoks (Redox potential) (mV) & -180.4 & -43.7 & -101.63 & 32.392 \\
\hline $\mathrm{NO}_{3}(\mathrm{mg} / \mathrm{L})$ & 0.0221 & 2.3673 & 0.2415 & 0.48811 \\
\hline $\mathrm{NO}_{2}(\mathrm{mg} / \mathrm{L})$ & 0.0002 & 0.0857 & 0.0349 & 0.03396 \\
\hline $\mathrm{NH}_{3}(\mathrm{mg} / \mathrm{L})$ & 0.0657 & 3.7307 & 0.7842 & 0.96337 \\
\hline $\mathrm{PO}_{4}(\mathrm{mg} / \mathrm{L})$ & 0.0001 & 1.9844 & 0.2971 & 0.52522 \\
\hline $\mathrm{Fe}(\mathrm{mg} / \mathrm{L})$ & 0.0001 & 0.0181 & 0.006 & 0.00414 \\
\hline $\mathrm{SO}_{4}(\mathrm{mg} / \mathrm{L})$ & $1,410.80$ & $2,401.80$ & $1,937.86$ & 312.046 \\
\hline $\mathrm{SiO}_{2}(\mathrm{mg} / \mathrm{L})$ & 0.0001 & 0,0531 & 0.014 & 0.01676 \\
\hline $\begin{array}{l}\text { Bahan organik total } \\
\text { Total organic matter }(\mathrm{mg} / \mathrm{L})\end{array}$ & 9.4926 & 59.0541 & 25.7855 & 12.09163 \\
\hline $\begin{array}{l}\text { Padatan tersuspensi total } \\
\text { Total suspended solid (mg/L) }\end{array}$ & 10 & 646 & 78.64 & 131.388 \\
\hline
\end{tabular}


Lanjutan Tabel 1 (Table 1 continued)

\begin{tabular}{|c|c|c|c|c|}
\hline $\begin{array}{l}\text { Fakt or/Peubah } \\
\text { Factor/Variable }\end{array}$ & Minimum & $\begin{array}{l}\text { Maksimum } \\
\text { Maximum }\end{array}$ & $\begin{array}{l}\text { Rata-rata } \\
\text { Average }\end{array}$ & $\begin{array}{l}\text { St andar deviasi } \\
\text { Standard } \\
\text { deviation }\end{array}$ \\
\hline \multicolumn{5}{|l|}{ Produksi : } \\
\hline $\begin{array}{l}\text { Produktivitas }(\mathrm{kg} / \mathrm{ha} / \text { musim) } \\
\text { Productivity ( } \mathrm{kg} / \mathrm{ha} / \text { season })\end{array}$ & 150 & 750 & 392.78 & 158.62 \\
\hline $\begin{array}{l}\text { Padat penebaran (ekor/ha) } \\
\text { Stocking density (ind./ha) }\end{array}$ & 500 & 25,000 & 4,127 & 5,356 \\
\hline $\begin{array}{l}\text { Berat saat panen (g/ekor) } \\
\text { Weight in harvest (g/ind.) }\end{array}$ & 200 & 450 & 300 & 78.68 \\
\hline $\begin{array}{l}\text { Lama pe meliharaan (hari) } \\
\text { Rearing period (days) }\end{array}$ & 150 & 160 & 158 & 4.3 \\
\hline
\end{tabular}

sedangkan $\mathrm{pH}_{\mathrm{FOx}}$ adalah $\mathrm{pH}$ tanah yang diukur di lapangan setelah dioksidasi sempurna dengan $\mathrm{H}_{2} \mathrm{O}_{2}$ (hidrogen peroksida) 30\% (Ahern \& Rayment, 1998). $\mathrm{pH}_{\mathrm{F}}$ dan $\mathrm{pH}_{\mathrm{FOX}}$ tanah tambak di Konawe Selatan rata-rata 6,70 dan 3,24. Nilai $\mathrm{pH}_{\mathrm{F}}-\mathrm{pH}_{\mathrm{FOX}}$ bervariasi dari 0,82 sampai 6,01 dengan rata-rata 3,46 . Hal ini menunjukkan bahwa potensi kemasaman tanah tambak di klaster Tinanggea relatif bervariasi.

Pada tanah sulfat masam yang dicirikan dengan kandungan pirit, maka salah satu sumber kemasamannya adalah sulfur. Pirit yang teroksidasi akan menghasilkan asam sulfat dan ferrosulfat yang apabila bereaksi dengan air melepaskan ferrisulfat yang selanjutnya apabila teroksidasi kembali akan menghasilkan asam sulfat. Sebagai sumber kemasaman yang penting pada tanah sulfat masam, maka sulfur yang diukur dalam bentuk $S_{\text {pos }}$ tanah telah digunakan oleh Ahern et al. (1998b) untuk menentukan kebutuhan kapur bagi tanah sulfat masam. Dari data yang ada menunjukkan bahwa kandungan $\mathrm{S}_{\text {pos }}$ tanah cukup tinggi yang berarti membutuhkan kapur yang tinggi pula. Kebutuhan kapur yang tinggi ditandai juga dengan kandungan unsur beracun seperti Fe (besi) dan Al (aluminium) yang tinggi juga. Kandungan Fe dan Al yang tinggi di klaster Tinanggea menyebabkan kandungan $\mathrm{PO}_{4}$ (fosfat) tanah relatif lebih rendah. Hal ini sebagai akibat dari Fe dan Al tanah yang dapat menyebabkan $\mathrm{PO}_{4}$ menjadi tidak tersedia. Pada tanah yang $\mathrm{pHnya}$ rendah, $\mathrm{PO}_{4}$ diikat secara kuat oleh Fe dan Al dalam bentuk $\mathrm{FePO}_{4}$ atau $\mathrm{AlPO}_{4}$ yang tidak larut (Mustafa \& Sammut, 2007).
Kandungan bahan organik tanah di tambak klaster Tinanggea bervariasi dari 2,77 sampai $19,34 \%$. Kandungan bahan organik tanah tambak ini tergolong tidak terlalu tinggi. Hal ini juga menunjukkan bahwa tanah tambak di klaster Tinanggea tidak tergolong sebagai tanah organosol atau tanah gambut. Tanah gambut adalah tanah yang dicirikan dengan kandungan bahan organik yang melebihi $20 \%$ (Boyd et al., 2002).

Rata-rata kandungan pasir umumnya cukup tinggi (lebih besar 70\%) dan sebaliknya kandungan liat sangat rendah (kurang dari 5\%) di tambak klaster Tinanggea. Tekstur tanah yang demikian tergolong tekstur yang kurang menguntungkan secara fisik untuk konstruksi pematang tambak. Secara kimia, tekstur tanah demikian juga tidak mampu menyimpan unsur hara dan memiliki daya sangga tanah yang rendah sehingga fluktuasi $\mathrm{pH}$ dapat lebih besar. Tanah tambak sering dijumpai bertekstur halus dengan kandungan liat minimal 20-30\% untuk menahan peresapan ke samping (Boyd, 1995).

Suhu air di tambak klaster Tinanggea berkisar antara $29,39^{\circ} \mathrm{C}$ sampai $36,44^{\circ} \mathrm{C}$ dengan rata-rata $32,95^{\circ} \mathrm{C}$ (Tabel 1). Suhu air yang tinggi terukur pada tambak yang airnya sangat dangkal (kurang dari $20 \mathrm{~cm}$ ). Suhu air yang baik untuk ikan bandeng adalah $27^{\circ} \mathrm{C}$ $31^{\circ} \mathrm{C}$ (Ismail et al., 1993).

Di klaster Tinanggea dijumpai banyak sungai yang tergolong sungai hidup yang berarti memiliki sumber air tawar. Hal ini terlihat jelas pada Tabel 1 di mana salinitas berkisar 
dari 2,63 sampai 31,04 ppt dengan rata-rata 13,42 ppt. Hal ini merupakan suatu kondisi yang sangat menguntungkan, sebab salinitas air relatif mudah diatur sesuai dengan tuntutan komoditas yang dibudidayakan, terutama pada lokasi yang dekat dengan sumber air tawar dan air asin. Ikan bandeng merupakan organisme eurihalin, namun karena dibudidayakan untuk tujuan komersial, kisaran salinitas yang optimum perlu dipertahankan. Ikan bandeng dapat tumbuh optimal pada salinitas air 15-30 ppt (Ismail et al., 1993).

Batas toleransi organisme akuatik terhadap $\mathrm{pH}$ bervariasi dan dipengaruhi oleh banyak faktor, antara lain: suhu oksigen terlarut, alkalinitas dan adanya anion dan kation serta jenis dan stadium organisme. Menurut Swingle (1968), pada umumnya $\mathrm{pH}$ air yang baik bagi organisme akuatik adalah 6,5-9,0; pada pH 9,511,0; dan 4,0-6,0 mengakibatkan produksi rendah dan jika lebih rendah dari 4,0 atau lebih tinggi 11,0 akan meracuni ikan. Dari Tabel 1 menunjukkan bahwa ada tambak di klaster Tinanggea yang $\mathrm{pH}$ air tergolong rendah. Telah dilaporkan sebelumnya, bahwa tambak di klaster Tinanggea tergolong tanah sulfat masam, sehingga $\mathrm{pH}$ airnya ada yang tergolong rendah. Hal ini dapat terjadi karena terjadi proses pembilasan dari pematang yang teroksidasi, sehingga menyebabkan $\mathrm{pH}$ air tambak menurun.

Oksigen terlarut sangat esensial bagi pernapasan dan merupakan salah satu komponen utama dalam metabolisme akuatik. Oksigen terlarut air tambak di klaster Tinanggea berkisar 5,85 sampai $9,42 \mathrm{mg} / \mathrm{L}$ dengan rata-rata 6,84 $\mathrm{mg} / \mathrm{L}$. Dalam hal ini, oksigen terlarut air tambak di klaster Tinanggea tergolong sesuai untuk budidaya tambak. Oleh karena budidaya yang diaplikasikan oleh pembudidaya tambak di klaster Tinanggea tergolong teknologi tradisional, sehingga masalah kandungan oksigen terlarut belum menjadi masalah. Ikan bandeng tumbuh dengan baik pada kisaran oksigen terlarut 3-8 mg/L (Ismail et al., 1993).

Seperti halnya dengan potensial redoks tanah, dari Tabel 1 terlihat bahwa potensial redoks air di klaster Tinanggea juga bernilai negatif yang berarti menunjukkan bahwa terjadi reaksi reduksi. Berdasarkan pendapat Tebbut (1992) maka air tambak di klaster Tinanggea tergolong kondisi anaerob sebab potensial redoksnya kurang dari $50 \mathrm{mV}$. Perairan alami biasanya memiliki nilai potensial redoks berkisar antara 45-52 mV (Effendi, 2003).
Nitrat $\left(\mathrm{NO}_{3}\right)$ adalah bentuk utama nitrogen di perairan alami dan merupakan nutrien utama bagi pertumbuhan tanaman dan alga. Nitrat tidak bersifat toksik terhadap organisme akuatik. Dari Tabel 1 terlihat bahwa kandungan nitrat air tambak di klaster Tinanggea berkisar antara 0,0221 sampai $2,3673 \mathrm{mg} / \mathrm{L}$ dengan rata-rata $0,2415 \mathrm{mg} / \mathrm{L}$. Kandungan nitrat ini juga tergolong tinggi. Kandungan $\mathrm{NO}_{3}$ pada perairan alami hampir tidak pernah lebih dari $0,1 \mathrm{mg} / \mathrm{L}$. Kandungan $\mathrm{NO}_{3}$ lebih dari $5 \mathrm{mg} / \mathrm{L}$ menggambarkan terjadinya pencemaran antropogenik yang berasal dari aktivitas manusia dan tinja hewan. Kandungan $\mathrm{NO}_{3}$ yang lebih dari $0,2 \mathrm{mg} / \mathrm{L}$ dapat mengakibatkan terjadinya eutrofikasi perairan yang selanjutnya menstimulir pertumbuhan alga dan tumbuhan air secara pesat. Kandungan $\mathrm{NO}_{3}$ dalam air tanah dapat mencapai $100 \mathrm{mg} / \mathrm{L}$. Air hujan memiliki kandungan $\mathrm{NO}_{3}$ sekitar $0,2 \mathrm{mg} / \mathrm{L}$ (Effendi, 2003).

Nitrit $\left(\mathrm{NO}_{2}\right)$ merupakan bentuk peralihan antara amonia dan nitrat (nitrifikasi) dan antara nitrat dan gas nitrogen (denitrifikasi). Seperti halnya $\mathrm{NH}_{3}$, maka $\mathrm{NO}_{2}$ juga beracun terhadap ikan, karena mengoksidasikan besi $(\mathrm{Fe}) \mathrm{di}$ dalam hemoglobin. Dalam bentuk ini kemampuan darah untuk mengikat oksigen terlarut sangat merosot (Poernomo, 1988). Pada udang yang darahnya mengandung tembaga $(\mathrm{Cu})$ (hemocyanin) mungkin terjadi oksidasi Cu oleh $\mathrm{NO}_{2}$ dan memberikan akibat yang sama seperti pada ikan (Smith \& Russo, 1975). Kandungan nitrit air tambak klaster Tinanggea berkisar 0,0002 sampai dengan $0,0857 \mathrm{mg} / \mathrm{L}$ dengan rata-rata $0,0349 \mathrm{mg} / \mathrm{L}$ yang tergolong tidak tinggi. Kandungan $\mathrm{NO}_{2}$ pada perairan relatif kecil karena segera dioksidasi menjadi nitrat. Perairan alami mengandung $\mathrm{NO}_{2}$ sekitar 0,001 $\mathrm{mg} / \mathrm{L}$ dan sebaliknya tidak melebihi $0,06 \mathrm{mg} / \mathrm{L}$ (Canadian Council of Resource and Environment Ministers, 1987 dalam Effendi, 2003). Di perairan, kandungan $\mathrm{NO}_{2}$ jarang melebihi 1 $\mathrm{mg} / \mathrm{L}$ (Sawyer \& McCarty, 1978). Kandungan $\mathrm{NO}_{2}$ yang lebih dari $0,05 \mathrm{mg} / \mathrm{L}$ dapat bersifat toksik bagi organisme akuatik yang sangat sensitif (Moore, 1991).

Amonia dapat berada dalam bentuk molekul $\left(\mathrm{NH}_{3}\right)$ atau bentuk ion $\mathrm{NH}_{4}$, di mana $\mathrm{NH}_{3}$ lebih beracun daripada $\mathrm{NH}_{4}$ (Poernomo, 1988). $\mathrm{NH}_{3}$ dapat menembus bagian membran sel lebih cepat daripada $\mathrm{NH}_{4}$ (Colt \& Armstrong, 1981). Kandungan amonia air tambak klaster Tinanggea berkisar antara 0,0067 sampai $1,3786 \mathrm{mg} / \mathrm{L}$ dengan rata-rata $0,2916 \mathrm{mg} / \mathrm{L}$. 
Kandungan $\mathrm{NH}_{3}$ 0,05-0,20 mg/L sudah menghambat pertumbuhan organisme akuatik pada umumnya. Apabila kandungan $\mathrm{NH}_{3}$ lebih dari $0,2 \mathrm{mg} / \mathrm{L}$, perairan bersifat toksik bagi beberapa jenis ikan (Sawyer \& McCarty, 1978). Berdasarkan informasi yang ada menunjukkan bahwa kandungan amonia air tambak klaster Tinanggea tergolong tinggi. Ikan tidak dapat bertoleransi terhadap kandungan $\mathrm{NH}_{3}$ yang terlalu tinggi, karena dapat mengganggu proses pengikatan oksigen oleh darah dan pada akhirnya dapat mengakibatkan sufokasi.

Di perairan, unsur fosfor tidak ditemukan dalam bentuk bebas sebagai elemen, melainkan dalam bentuk senyawa anorganik yang terlarut (ortofosfat dan polifosfat) dan senyawa organik yang berupa partikulat. Fosfat merupakan bentuk fosfor yang dapat dimanfaatkan oleh tumbuhan (Dugan, 1972). Kandungan $\mathrm{PO}_{4}$ jarang melebihi $0,1 \mathrm{mg} / \mathrm{L}$, meskipun pada perairan eutrof. Kandungan $\mathrm{PO}_{4}$ pada perairan alami jarang melebihi $1 \mathrm{mg} / \mathrm{L}$ (Boyd, 1988). Berdasarkan kandungan fosfat, perairan diklasifikasikan menjadi tiga yaitu: perairan dengan kesuburan rendah, yang memiliki kandungan fosfat berkisar antara 0-0,02 mg/L; perairan dengan tingkat kesuburan sedang, yang memiliki kandungan fosfat 0,021-0,05 mg/L; dan perairan dengan tingkat kesuburan tinggi, yang memiliki kandungan fosfat 0,051-0,10 mg/L (Yoshimura, 1966 dalam Liaw, 1969). Berdasarkan kriteria tersebut menunjukkan bahwa kualitas air tambak di klaster Tinanggea tergolong tingkat kesuburan rendah, sedang, dan tinggi.

Silika (Si) telah sebagai unsur konservatif dari mineral di mana air tawar di sungai di seluruh dunia mengandung rata-rata Si setara 6,1 mg/L (Boyd, 1982). Kandungan $\mathrm{SiO}_{2}$ air tambak di klaster Tinanggea berkisar dari 0,0001 sampai $0,0531 \mathrm{mg} / \mathrm{L}$ dengan rata-rata 0,0140 mg/L. Silika dibutuhkan untuk pertumbuhan diatom. Telah dibuktikan bahwa dalam beberapa kandungan silika perairan dapat mengatur kelimpahan diatom (Fogg, 1974).

Bahan organik total air menggambarkan kandungan bahan organik total suatu perairan yang terdiri atas bahan organik terlarut, tersuspensi dan koloid. Bahan organik di perairan terdapat sebagai plankton, partikel-partikel tersuspensi dari bahan organik yang mengalami perombakan (detritus) dan bahan-bahan organik total yang berasal dari daratan dan terbawa oleh aliran sungai. Kandungan bahan organik total air di tambak klaster Tinanggea berkisar 9,4926 dan 59,0541 mg/L dengan rata-rata $25,7855 \mathrm{mg} / \mathrm{L}$ (Tabel 1). Kandungan bahan organik total dalam air laut biasanya rendah dan tidak melebihi $3 \mathrm{mg} / \mathrm{L}$. Menurut Reid (1961), perairan dengan kandungan bahan organik total di atas $26 \mathrm{mg} / \mathrm{L}$ adalah tergolong perairan yang subur.

Padatan tersuspensi total menggambarkan bahan baik organik maupun nonorganik yang terkandung dalam larutan dalam bentuk tersuspensi. Menurut Effendi (2003), padatan tersuspensi total yaitu bahan-bahan tersuspensi berukuran diameter $>1 \mu \mathrm{m}$, tertahan pada saringan millipore berdiameter pori 0,45 $\mu \mathrm{m}$. Padatan tersuspensi total berupa lumpur, pasir halus dan jasad renik yang melayang-layang di perairan. Padatan tersuspensi total air tambak di klaster Tinanggea berkisar antara 10,00 sampai $646,00 \mathrm{mg} / \mathrm{L}$ dengan rata-rata 78,64 $\mathrm{mg} / \mathrm{L}$.

\section{Hubungan Lingkungan dan Produksi Tambak}

Telah dijelaskan sebelumnya bahwa peubah kualitas tanah merupakan peubah bebas dan peubah eksogen dalam penelitian ini. Dari 20 peubah kualitas tanah (Tabel 1) yang dianalisis ternyata hanya dua peubah yang mempengaruhi produksi ikan bandeng di tambak tanah sulfat masam klaster Tinanggea yaitu: $\mathrm{pH}_{\mathrm{FOx}}$ tanah $\left(\mathrm{pH}_{\mathrm{FOX}} \mathrm{T}\right)$ dan potensial redoks tanah (EhT) (Gambar 1). $\mathrm{pH}_{\mathrm{FOX}}{ }^{\top}$ hanya berpengaruh nyata dengan pengaruh langsung (direct effect) sebesar $0,454(P<0,10)$ terhadap produksi, sedangkan EhT berpengaruh sangat nyata dengan pengaruh langsung sebesar $-0,540(P<0,01)$ terhadap produksi. Dari 14 peubah kualitas air yang merupakan peubah perantara, tergantung dan endogen dalam penelitian ini, ternyata hanya tiga peubah yang mempengaruhi produksi ikan bandeng di tambak tanah sulfat masam klaster Tinanggea yaitu: padatan tersuspensi total air (PTTA), $\mathrm{pH}$ air (pHA), dan potensial redoks air (EhA) (Gambar 1). PTTA, pHA, dan EhA hanya berpengaruh nyata $(P<0,10)$ dengan pengaruh langsung masing-masing $-0,343$, 0,532 , dan $-0,500$ terhadap produksi. Kedua peubah kualitas tanah yang berpengaruh terhadap produksi tersebut ternyata berpengaruh pula terhadap kualitas air tambak, tetapi hanya pada peubah pHA dan EhA. $\mathrm{pH}_{\mathrm{Fox}}{ }^{\top}$ hanya berpengaruh nyata $(P<0,10)$ terhadap pHA dan EhA dengan pengaruh langsung masing-masing 0,365 dan -0,367. EhT ber- 


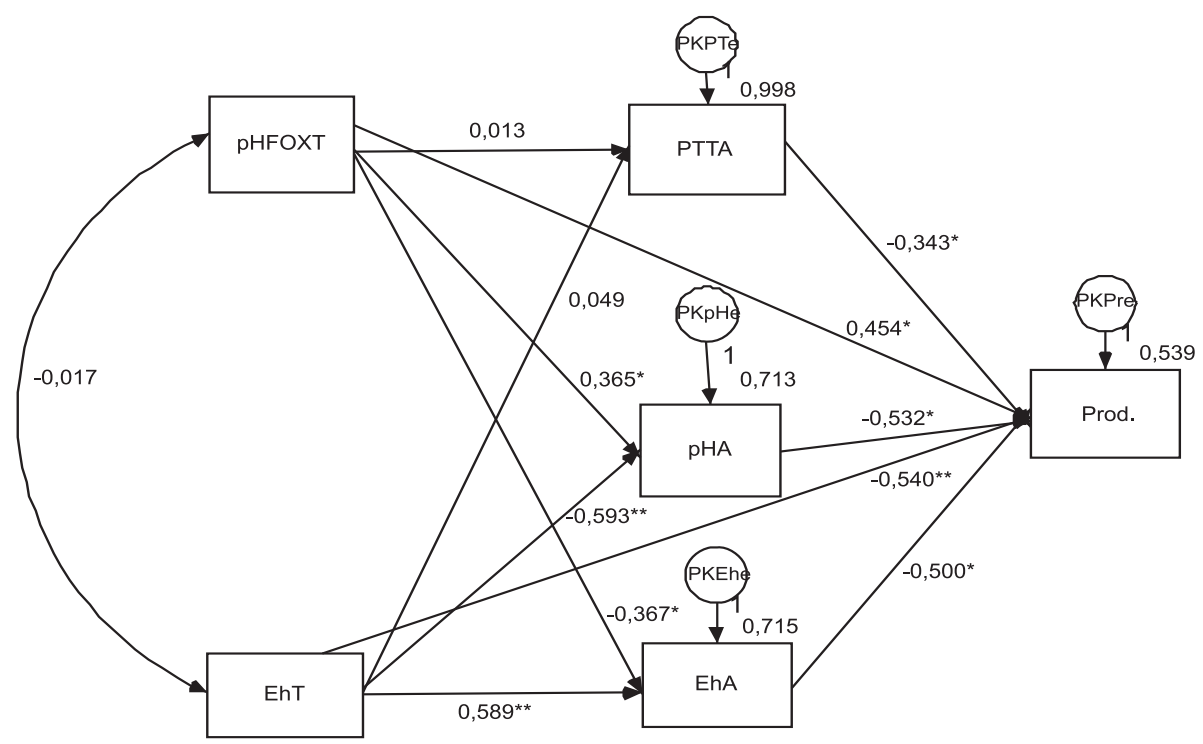

Keterangan (Note):

$\mathrm{pH}_{\mathrm{FOX}}{ }^{\top}: \mathrm{pH}_{\mathrm{FOX}}$ tanah ( $\mathrm{pH}_{\mathrm{FOX}}$ of soil)

$\mathrm{S}_{\mathrm{KCl}}{ }^{\top}: \mathrm{S}_{\mathrm{KCl}} \operatorname{tanah}\left(\mathrm{S}_{\mathrm{KCl}}\right.$ of soil)

EhT : Potensial redoks tanah (Redox potential of soil)

PTTA : Padatan tersuspensi total air (Total suspended solid of water)

pHA : $\mathrm{pH}$ air (Water $\mathrm{pH})$

EhA : Potensial redoks air (Redox potential of water)

Prod. : Produksi (Production)

Gambar 1. Diagram hasil analisis jalur dari pengaruh kualitas tanah terhadap kualitas air dan produksi ikan bandeng di tambak klaster Tinanggea, Kabupaten Konawe Selatan Provinsi Sulawesi Tenggara

Figure 1. Flow of path analysis result of soil quality effect on water quality and milkfish production in brackishwater ponds of Tinanggea cluster, South Konawe Regency Southeast Sulawesi Province

pengaruh sangat nyata $(\mathrm{P}<0,01)$ terhadap $\mathrm{pHA}$ dan EhA dengan pengaruh langsung masingmasing $-0,593$ dan 0,589. Dalam hal ini, pengaruh nyata kualitas tanah terhadap produksi adalah melalui peubah perantara kualitas air yaitu pHA dan EhA. Pengaruh langsung, tidak langsung, dan total antar peubah secara lengkap tersaji pada Tabel 2 .

Telah disebutkan sebelumnya bahwa $\mathrm{pH}_{\mathrm{FOX}}{ }^{\top}$ berpengaruh langsung terhadap produksi ikan bandeng di tambak klaster Tinanggea. Tanah sulfat masam dapat menyebabkan rendahnya produktivitas tambak sebagai akibat asam sulfurik yang terbentuk karena teroksidasinya pirit akan mempengaruhi mineral-mineral tanah. Pembebasan besi dan aluminium akan mengikat fosfat dan hara esensial lainnya yang akan menyebabkan pupuk tidak berdaya guna dan selanjutnya menyebabkan rendahnya produktivitas alami tambak. Akibat lain kehadiran asam sulfat menyebabkan lambatnya pertumbuhan tanaman penutup pematang sehingga pematang mudah tererosi. Tanah pematang yang mengandung asam sulfat, aluminium, dan besi bila tercuci lewat erosi dan masuk ke dalam tambak dapat memperburuk kondisi kualitas air (Brinkman \& Singh, 1982) dan akhirnya menurunkan produktivitas tambak.

$\mathrm{pH}_{\text {Fox }}{ }^{\top}$ mempengaruhi produksi ikan bandeng juga melalui pengaruh tidak langsung yaitu mempengaruhi pHA dan EhA. Pada tanah sulfat masam, tanah dasar atau tanah pematang yang terekspos dengan udara dapat menyebabkan terlarutnya pirit yang melarutkan asam sulfat, besi, dan alauminium yang dapat menye- 
Tabel 2. Nilai pengaruh langsung, tidak langsung dan total setiap korelasi dalam analisis jalur untuk faktor lingkungan dan produksi ikan bandeng di tambak tanah sulfat masam klaster Tinanggea, Kabupaten Konawe Selatan

Table 2. Values of direct, indirect and total effects of each correlation in path analysis for environmental factors and milkfish production in acid sulfate soil-affected brackishwater ponds of Tinanggea cluster, South Konawe Regency

\begin{tabular}{|c|c|c|c|c|}
\hline \multicolumn{2}{|c|}{$\begin{array}{c}\text { Korelasi dalam } \\
\text { analisis Jalur } \\
\text { Correlation in path analysis }\end{array}$} & \multirow{2}{*}{$\begin{array}{c}\begin{array}{c}\text { Pengaruh } \\
\text { langsung } \\
\text { Direct effect }\end{array} \\
0.013\end{array}$} & \multirow{2}{*}{$\begin{array}{c}\begin{array}{c}\text { Pengaruh } \\
\text { tidak langsung } \\
\text { Indirect effect }\end{array} \\
-0.001\end{array}$} & \multirow{2}{*}{$\begin{array}{c}\begin{array}{c}\text { Pengaruh } \\
\text { total } \\
\text { Total effect }\end{array} \\
0.012\end{array}$} \\
\hline $\mathrm{pH}_{\mathrm{FOX}}{ }^{\top}$ & $\rightarrow$ PTTA & & & \\
\hline $\mathrm{pH}_{\mathrm{FOX}}{ }^{\top}$ & $\rightarrow \mathrm{pHA}$ & 0.365 & 0.01 & 0.375 \\
\hline $\mathrm{pH}_{\mathrm{FOX}}{ }^{\top}$ & $\rightarrow$ EhA & -0.367 & -0.01 & -0.377 \\
\hline $\mathrm{pH}_{\mathrm{FOX}}{ }^{\top}$ & $\rightarrow$ Prod. & 0.454 & -0.006 & 0.448 \\
\hline EhT & $\rightarrow$ PTTA & 0.049 & -0.001 & 0.048 \\
\hline EhT & $\rightarrow \mathrm{pHA}$ & -0.593 & -0.006 & -0.599 \\
\hline EhT & $\rightarrow$ EhA & 0.589 & 0.006 & 0.595 \\
\hline EhT & $\rightarrow$ Prod. & -0.54 & -0.003 & -0.543 \\
\hline PTTA & $\rightarrow$ Prod. & -0.343 & -0.02 & -0.363 \\
\hline $\mathrm{pHA}$ & $\rightarrow$ Prod. & 0.532 & 0.074 & 0.606 \\
\hline EhA & $\rightarrow$ Prod. & -0.5 & -0.242 & -0.742 \\
\hline
\end{tabular}

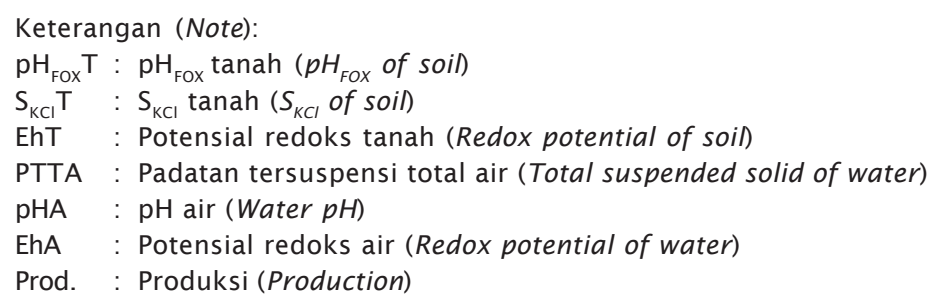

babkan penurunan $\mathrm{pH}$ air. Tanah-tanah pada sistem persawahan dan penggenangan akan mendorong perubahan elektrokimia yang mempengaruhi penyediaan dan pengambilan hara (Ponnamperuma, 1985). Perubahan sifatsifat kimia dimaksud antara lain terjadinya perubahan potensial redoks (Eh) dan kemasaman tanah $(\mathrm{pH})$ tanah yang merupakan dua faktor utama yang saling berkaitan dalam mempengaruhi kelarutan dan ketersediaan hara dan transformasinya di dalam tanah serta berpengaruh terhadap pertumbuhan dan produksi tambak. Pada tanah sulfat masam yang tergenang terjadi perubahan bentuk $\mathrm{Fe}^{+3}$ menjadi $\mathrm{Fe}^{+2}$ yang terjadi karena adanya perubahan suasana oksidatif menjadi reduktif. Reaksi tersebut melibatkan aktivitas mikroba tanah menstimulasi proses reduksi $\mathrm{Fe}^{+3}$ menjadi $\mathrm{Fe}^{+2}$, meningkatkan $\mathrm{pH}$, menurunkan Eh, dan terjadi peningkatan ketersediaan P. Dalam hal ini menunjukkan bahwa sebagai akibat penggenangan tambak tanah sulfat masam menyebabkan peningkatan $\mathrm{pHT}$ dan penurunan EhA seperti terlihat pada Gambar 1 dan Tabel 2. Ponnamperuma et al. (1969) menyatakan Eh mengalami penurunan dari $700 \mathrm{mV}$ sampai -300 mV, sedangkan $\mathrm{pH}$ tanah berubah dari 4,5 menjadi $6,5-7,0$ pada tanah sulfat masam yang digenangi.

EhT memberikan pengaruh terhadap produksi ikan bandeng di tambak klaster Tinanggea. Pengeringan tanah dasar tambak dapat meningkatkan EhT yang berarti pula menyebabkan pirit teroksidasi yang melarutkan asam sulfat, aluminium dan besi yang menyebabkan penurunan $\mathrm{pH}$ tanah dan air yang selanjutnya menyebabkan pertumbuhan makanan alami menjadi terhambat, sehingga produksi ikan bandeng menurun. Hal ini sangat jelas terlihat pada Gambar 1 dan Tabel 2 di 
mana peningkatan EhT menyebabkan penurunan pHA dan peningkatan EhA. Aleshire (2000) menyatakan bahwa peningkatan $\mathrm{pH}$ tanah menyebabkan penurunan potensial redoks. Sebelumnya telah dikatakan oleh Gambrell \& Patrick (1978) bahwa hubungan antara $\mathrm{pH}$ dan potensial redoks sangat nyata pada sistem alami, akan tetapi pada berbagai kasus sangat sulit menentukan hubungan tersebut. Diduga, pengeringan yang dilakukan oleh pembudidaya tambak di klaster Tinanggea bukan dilakukan untuk remediasi tanah dasar tambak, tetapi hanya untuk pengeringan tanah dasar tambak, sebagai akibatnya justru menurunkan $\mathrm{pH}$ tanah maupun $\mathrm{pH}$ air. Dalam hal ini, pengeringan tanah dasar tambak menyebabkan pirit teroksidasi dan menghasilkan unsur atau senyawa penyebab kemasaman tanah dan air.

Padatan tersuspensi total berupa lumpur, pasir halus dan jasad renik yang melayanglayang di perairan. PTTA memberikan pengaruh nyata $(P<0,10)$ terhadap produksi ikan bandeng di tambak klaster Tinanggea dengan pengaruh langsung -0,343. Hal ini menunjukkan bahwa makin tinggi PTTA maka produksi ikan bandeng akan mengalami penurunan. Peningkatan kandungan PTTA akan menyebabkan badan air akan mulai kehilangan kemampuan dalam mendukung diversitas organisme akuatik. Makin tinggi kandungan PTTA maka kemampuan air menyerap panas dari matahari juga meningkat yang berarti juga meningkatkan suhu air dan sebagai konsekuensinya adalah terjadi penurunan kandungan oksigen terlarut. Fotosintesis juga menurun, karena berkurangnya penetrasi matahari yang masuk dalam air. Sebagai akibatnya oksigen terlarut yang diproduksi oleh tanaman air maupun alga juga berkurang, turut mempercepat penurunan kandungan oksigen terlarut. Hal inilah yang menyebabkan peningkatan kandungan PTTA di tambak yang menyebabkan penurunan produksi ikan bandeng di tambak klaster Tinanggea. Seperti dikatakan oleh Boyd (1995) padatan tersuspensi total dapat juga membahayakan ikan secara langsung melalui penyumbatan insang, penurunan pertumbuhan, dan penurunan daya tahan terhadap penyakit.

\section{KESIMPULAN DAN SARAN}

Tambak di klaster Tinanggea (Kabupaten Konawe Selatan) didominasi oleh tanah sulfat masam dengan potensi kemasaman tinggi, kandungan unsur toksik yang tinggi, kan- dungan unsur hara makro yang rendah, dan tekstur tanah yang tergolong kasar. Secara umum, kualitas air dapat mendukung usaha budidaya ikan bandeng (Chanos chanos) di tambak. Dari 20 peubah kualitas tanah (sebagai peubah bebas dan peubah eksogen) yang dianalisis ternyata hanya dua peubah yang mempengaruhi produksi ikan bandeng yaitu: $\mathrm{pH}_{\mathrm{Fox}}$ tanah dan potensial redoks tanah, sedangkan dari 14 peubah kualitas air (sebagai peubah perantara, tergantung dan endogen), ternyata hanya tiga peubah yang mempengaruhi produksi ikan bandeng di tambak tanah sulfat masam klaster Tinanggea yaitu: padatan tersuspensi total air, $\mathrm{pH}$ air, dan potensial redoks air. $\mathrm{pH}_{\mathrm{FOx}}$ tanah hanya berpengaruh nyata dengan pengaruh langsung sebesar 0,454 terhadap produksi, sedangkan potensial redoks tanah berpengaruh sangat nyata dengan pengaruh langsung sebesar -0,540 terhadap produksi. Padatan tersuspensi total air, $\mathrm{pH}$ air, dan potensial redoks air hanya berpengaruh nyata dengan pengaruh langsung masing-masing $-0,343,0,532$, dan $-0,500$ terhadap produksi. Kedua peubah kualitas tanah yang berpengaruh terhadap produksi tersebut ternyata berpengaruh pula terhadap kualitas air tambak, tetapi hanya pada peubah $\mathrm{pH}$ air dan potensial redoks air. Oleh karena itu perbaikan $\mathrm{pH}$ dan potensial redoks tanah serta padatan tersuspensi total, $\mathrm{pH}$, dan potensial redoks air menjadi penting diperhatikan dalam upaya peningkatan produksi ikan bandeng di tambak klaster Tinanggea, Kabupaten Konawe Selatan.

\section{UCAPAN TERIMA KASIH}

Diucapkan banyak terima kasih kepada Muhammad Arnold dan Ilham atas bantuannya di lapangan; Rosiana Sabang, Rahmiyah, dan Kamariah atas bantuannya dalam analisis kualitas tanah; serta Sutrisyani, Sitti Rohani, Andi Sahrijanna, dan Kurniah atas bantuannya dalam analisis air.

\section{DAFTAR ACUAN}

Agus, Yusrial, F., \& Sutono. 2006. Penetapan tekstur tanah. Dalam: Kurnia, U., Agus, F., Adimihardja, A. dan Dariah, A. (eds.). Sifat Fisik Tanah dan Metode Analisisnya. Balai Besar Penelitian dan Pengembangan Sumberdaya Lahan Pertanian, Bogor, hlm. 43-62.

Ahern, C.R., Blunden, B., Sullivan, L.A., \& McElnea, A.E. 2004. Soil sampling, handling, 
preparation and storage for analisys of dried samples. In: Acid Sulfate Soils Laboratory Methods Guidelines. Queensland Department of Natural Resources, Mines and Energy, Indooroopilly, Queensland, Australia, p. B1-1-B1-5.

Ahern, C.R. \& McElnea, A.E. 2004. Calculated sulfur parameters. In: Acid Sulfate Soils Laboratory Methods Guidelines. Queensland Department of Natural Resources, Mines and Energy, Indooroopilly, Queensland, Australia, p. B11-1-B11-2.

Ahern, C.R., McElnea, A., \& Baker, D.E. 1998a. Acid neutralizing capacity methods. In: Ahern, C.R., Blunden, B., and Stone, Y. (eds.), Acid Sulfate Soils Laboratory Methods Guidelines. Acid Sulfate Soil Management Advisory Committee, Wollongbar, NSW, p. 6.1-6.4.

Ahern, C.R., McElnea, A., \& Baker, D.E. 1998b. Peroxide oxidation combined acidity and sulfate. In: Ahern, C.R., Blunden, B., \& Stone, Y. (eds.), Acid Sulfate Soils Laboratory Methods Guidelines. Acid Sulfate Soil Management Advisory Committee, Wollongbar, NSW, p. 4.1-4.17.

Aleshire, D.R. 2000. Relationship among Soil $p H$, Redox Potential, and Ferrous Iron Content Data Obtained from Various Field and Lab Methods. Bachelor of Science Thesis. Oregon State University, Corvallis, Oregon, $27 \mathrm{pp}$.

Amir, M.F. 2006. Mengolah dan Membuat Interpretasi Hasil Olahan SPSS untuk Penelitian Ilmiah. EDSA Mahkota, Jakarta, $201 \mathrm{hlm}$.

Anonim. 2010. Konawe Selatan dalam Angka 2010. BPS Kabupaten Konawe Selatan, Andoolo, $290 \mathrm{hlm}$.

APHA (American Public Health Association). 2005. Standard Methods for Examination of Water and Wastewater. Twentieth edition APHA-AWWA-WEF, Washington, 1,185 pp.

Boyd, C.E. 1988. Water Quality of Warmwater Fish Ponds. Fourth printing. Alabama Agricultural Experiment Station, Auburn University, Alabama, 359 pp.

Boyd, C.E. 1989. Water Quality Management and Aeration in Shrimp Farming. Fisheries and Allied Aquacultures Department Seri No. 2. Alabama Agricultural Experiment Station, Auburn University, Auburn, $82 \mathrm{pp}$.

Boyd, C.E. 1995. Bottom Soils, Sediment, and Pond Aquaculture. Chapman and Hall, New York, $348 \mathrm{pp}$.
Boyd, C.E., Wood, C.W., and Thunjai, T. 2002. Aquaculture Pond Bottom Soil Quality Management. Pond Dynamics/Aquaculture Collaborative Research Support Program Oregon State University, Corvallis, Oregon, $41 \mathrm{pp}$.

Brinkman, R. \& Singh, V.P. 1982. Rapid reclamation of brackish water fishpond in acid sulfate soils. In: Dost, $\mathrm{H}$. and van Breemen, $\mathrm{N}$. (eds.), Proceedings of the Bangkok Symposium on Acid Sulphate Soils. ILRI Publication 31. International Institute of Land Reclamation and Improvement, Wageningen, $\mathrm{p}$. 318-330.

Colt, J.E. \& Armstrong, D.A. 1981. Nitrogen toxicity to crustaceans, fish, and molluscs. In: Allen, L.J. and Kinney, E.C. (eds.), Proceedings of the Bio-engineering Symposium for Fish Culture. American Fisheries Society, Bethesda, M.D., p. 34-37.

Dent, D. 1986. Acid Sulphate Soils: A Baseline for Research and Development. ILRI Publication 39. International Institute for Land Reclamation and Improvement, Wageningen, $204 \mathrm{pp}$.

Draper, N.R. \& Smith, H. 1981. Applied Regression Analysis. Second edition. John Wiley \& Sons, New York, 709 pp.

Dugan, P.R. 1972. Biochemical Ecology of Water Pollution. Plenum Press, New York. 159 pp.

Effendi, H. 2003. Telaah Kualitas Air bagi Pengelolaan Sumber Daya dan Lingkungan Perairan. Penerbit Kanisius, Yogyakarta, 258 hlm.

Everitt, B.S. \& Dunn, G. 2001 . Applied Multivariate Data Analysis. Second edition. Arnold, London. 342 pp.

Eviati \& Sulaeman. 2009. Analisis Kimia Tanah, Tanaman, Air, dan Pupuk. Petunjuk Teknis Edisi 2. Balai Penelitian Tanah, Bogor, 234 hlm.

Fogg, G.E. 1974. Nitrogen fixation. In: Stewart, W.D.P. (ed.), Algal Physiology and Biochemistry. Botanical Monographs. Volume 10. Blackwell Scientific Publication, Oxford, p. 560-582.

Gambrell, R.P. \& PatrickJr., W.H. 1978. Chemical and microbiological properties of anaerobic soils and sediments. In: Hook, D.D. and Crawford, R.M. (eds.), Plant Life in Anaerobic Environments. Ann Arbor Science Publisher, Inc., Ann Arbor, Michigan, p. 375423. 
Hardjowigeno, S., Soekardi, M., Djaenuddin, D., Suharta, N., \& Jordens, E.R. 1996. Kesesuaian Lahan untuk Tambak. Pusat Penelitian Tanah dan Agroklimat, Bogor, 17 hlm.

Ismail, A., Poernomo, A., Sunyoto, P., Wedjatmiko, Dharmadi, \& Budiman, R.A.I. 1993. Pedoman Teknis Usaha Pembesaran Ikan Bandeng di Indonesia. Pusat Penelitian dan Pengembangan Perikanan, Jakarta, $93 \mathrm{hlm}$.

Karthik, M., Suri, J., Saharan, N., \& Biradar, R.S. 2005. Brackish water aquaculture site selection in Palghar Taluk, Thane district of Maharashtra, India, using the techniques of remote sensing and geographical information system. Aquacultural Engineering, 32: 285-302.

Liaw, W.K. 1969. Chemical and biological studies of fishponds and reservoirs in Taiwan. Reprinted from Chinese-American Joint Commission on Rural Reconstruction, Fish Series, 7: 1-43.

Lin, C., Wood, W., Heskins, P., Ryffel, T., \& Lin, J. 2004. Controls on water acidification and de-oxygenation in an estuarine waterway, eastern Australia. Estuarine Coastal and Shelf Science, 61: 55-63.

McElnea, A.E. \& Ahern, C.R. 2004a. KCl extractable $\mathrm{pH}\left(\mathrm{pH}_{\mathrm{KCI}}\right)$ and titratable actual acidity (TAA). In: Acid Sulfate Soils Laboratory Methods Guidelines. Queensland Department of Natural Resources, Mines and Energy, Indooroopilly, Queensland, Australia, p. B21-B2-3.

McElnea, A.E. \& Ahern, C.R. 2004b. Peroxide $\mathrm{pH}\left(\mathrm{pH}_{\mathrm{ox}}\right)$, titartable peroxide acidity (TPA) and excess acid neutralising capacity $\left(\mathrm{ANC}_{\mathrm{E}}\right.$ ). In: Acid Sulfate Soils Laboratory Methods Guidelines. Queensland Department of Natural Resources, Mines and Energy, Indooroopilly, Queensland, Australia. p. B3-1-B3-7.

McElnea, A.E. \& Ahern, C.R. 2004c. Sulfur-peroxide oxidation method. In: Acid Sulfate Soils Laboratory Methods Guidelines. Queensland Department of Natural Resources, Mines and Energy, Indooroopilly, Queensland, Australia, p. B7-1-B7-2.

McElnea, A.E. \& Ahern, C.R. 2004d. Sulfur $1 \mathrm{M}$ $\mathrm{KCl}$ extraction $\left(\mathrm{S}_{\mathrm{KCl}}\right)$. In: Acid Sulfate Soils Laboratory Methods Guidelines. Queensland Department of Natural Resources, Mines and Energy, Indooroopilly, Queensland, Australia, p. B8-1-B8-2.
Melville, M.D. 1993. Soil Laboratory Manual. School of Geography, The University of New South Wales, Sydney, 74 pp.

Menon, R.G. 1973. Soil and Water Analysis: A Laboratory Manual for the Analysis of Soil and Water. Proyek Survey O.K.T. Sumatera Selatan, Palembang, 190 pp.

Moore, J.W. 1991. Inorganic Contaminants of Surface Water. Springer-Verlag, New York. $334 \mathrm{pp}$.

Muir, J.F. \& Kapetsky, J.M. 1988. Site selection decisions and project cost: the case of brackish water pond systems. In: Aquaculture Engineering Technologies for the Future. Hemisphere Publishing Corporation, New York, p. 45-63.

Mustafa, A. 2007. Improving Acid Sulfate Soils for Brackish Water Ponds in South Sulawesi, Indonesia. Doctor of Philosophy Thesis. The University of New South Wales, Sydney, $418 \mathrm{pp}$.

Mustafa, A., Rachmansyah, \& Hanafi, A. 2007. Kelayakan Lahan untuk Budi Daya Perikanan Pesisir. Dalam: Kumpulan Makalah Bidang Riset Perikanan Budidaya. Disampaikan pada Simposium Kelautan dan Perikanan pada tanggal 7 Agustus $2007 \mathrm{di}$ Gedung Bidakara, Jakarta. Pusat Riset Perikanan Budidaya, Jakarta, $28 \mathrm{hlm}$.

Mustafa, A. \& Sammut, J. 2007. Effect of different remediation techniques and dosages of phosphorus fertilizer on soil quality and klekap production in acid sulfate soilaffected aquaculture ponds. Indonesian Aquaculture Journal, 2(2): 141-157.

Mustafa, A. \& Ratnawati, E. 2005. Faktor pengelolaan yang berpengaruh terhadap produksi rumput laut (Gracilaria verrucosa) di tambak tanah sulfat masam (studi kasus di Kabupaten Luwu, Provinsi Sulawesi Selatan). Jurnal Penelitian Perikanan Indonesia, 11 (7): 67-77.

Parsons, T.R., Maita, Y., \& Lalli. C.M. 1989. A Manual of Chemical and Biological Methods for Seawater Analysis. Pergamon Press, Oxford, $173 \mathrm{pp}$.

Poernomo, A. 1988. Pembuatan Tambak Udang di Indonesia. Seri Pengembangan No. 7. Balai Penelitian Perikanan Budidaya Pantai, Maros, $40 \mathrm{hlm}$.

Ponnamperuma, F.N. 1984. Effects of flooding on soils. In: Koslowski, T.T. (ed.), Flooding and Plant Growth. Academic Press, Inc., New York, p. 10-45. 
Reid, G.K. 1961. Ecology of Inland Waters and Estuaries. Van Nostrand Reinhold Co., New York, $375 \mathrm{pp}$.

Rutherford, R.D. \& Choe, M.K. 1993. Statistical Models for Causal Analysis. John Wiley \& Sons, Inc., New York, 216 pp.

Salam, M.A., Ross, L.G., \& Beveridge, C.M.M. 2003. A comparison of development opportunities for crab and shrimp aquaculture in southwestern Bangladesh, using GIS modeling. Aquaculture, 220: 477-494.

Sammut, J. \& Lines-Kelly, R. 2000. An Introduction to Acid Sulfate Soils. Natural Heritage Trust, Australia, $27 \mathrm{pp}$.

Sammut, J. 1999. Amelioration and management of shrimp ponds in acid sulfate soils: key researchable issues. In: Smith, P.T. (ed.), Towards Sustainable Shrimp Culture in Thailand and the Region. ACIAR Proceedings No. 90. Australian Centre for International Agricultural Research, Canberra, p. 102106.

Sarwono, J. 2007. Analisis Jalur untuk Riset Bisnis dengan SPSS. Penerbit Andi, Yogyakarta, $321 \mathrm{hlm}$.

Sawyer, C.N. \& McCarty, P.L. 1978. Chemistry for Environmental Engineering. Third edition. McGraw-Hill Book Company, New York, $532 \mathrm{pp}$.
Schaetzl, R.J. \& Anderson, S. 2005. Soils: Genesis and Geomorphology. Cambridge University Press, Cambridge, $817 \mathrm{pp}$.

Smith, C.E. \& Russo, R.C. 1975. Nitrite-induced methemoglobinemia in rainbow trout. Progressive Fish-Culturist, 37: 150-151.

Suliyanto. 2011 . Ekonometrika Terapan: Teori \& Aplikasi dengan SPSS. Penerbit Andi, Yogyakarta, $311 \mathrm{hlm}$.

Supranto, J. 2004. Analisis Multivariat: Arti \& Interpretasi. Cetakan pertama. Rineka Cipta, Jakarta, $359 \mathrm{hlm}$.

Sutrisyani \& Rohani, S. 2009. Panduan Praktis Analisis Kualitas Air Payau. Diedit: Rachmansyah, Atmomarsono, M., dan Mustafa, A. Cetakan kedua. Pusat Riset Perikanan Budidaya, Jakarta, $55 \mathrm{hlm}$.

Swingle, H.S. 1968. Standardization of chemical analysis for waters and pond muds. FAO Fisheries Report, 44(4): 397-406.

Tebbut, T.H.Y. 1992. Principles of Water Quality Control. Fourth edition. Pergamon, Oxford, U.K., 251 pp.

Treece, G.D. 2000. Site selection. In: Stickney, R.R. (ed.), Encyclopedia of Aquaculture. John Wiley \& Sons, Inc., New York, p. 869-879.

Widarjono, A. 2010. Analisis Statistika Multivariat Terapan. Edisi pertama. UPP STIM YKPN, Yogyakarta, $358 \mathrm{hlm}$. 